\title{
Editorial - The 2015 African Journal Partnership Project Meeting in Malawi: Continental progress via continental breakfasts and intercontinental collaboration
}

\section{Andrew A. Mataya \\ Malawi Medical Journal}

This June 2015 issue of the Malawi Medical Journal is published on the back of Malawi's hosting of the 11th annual African Journal Partnership Project (AJPP) Meeting, held on 11 and 12 June at Game Haven Lodge, Chimwenya Game Park in Bvumbwe. And what a captivating, inspiring meeting it was. Indeed, it was captivating enough to inspire me to write my first editorial as $M M J$ intern-to express, to the $M M J$ audience, just how lively and infectious the enthusiasm was in that boardroom over those two enlightening days. This year's theme was "Promoting Scientific Integrity for African Medical Science and Journals". We welcomed AJPP codirectors Annette Flanagin (of the Journal of the American Medical Association, JAMA), David Ofori-Adjei (of the Ghana Medical Journal), and Steve Morrissey (of the New England Journal of Medicine). Editors and representatives of the thirteen journals that make up the AJPP and representatives of the programme's various sponsoring and supporting organizations were also in attendance.

For those of you who are unfamiliar with the AJPP, let me start with a bit of background. ${ }^{1,2}$ The AJPP was born out of an idea conceived, in 2003, by the Fogarty International Center (FIC) and the National Library of Medicine (NLM), both of which are entities operated by the United States federal government under the National Institutes of Health (NIH) umbrella. The idea was to address the need for capacity building among Africa's biomedical and health journals by partnering a select few of them with leading biomedical journals in the United States and the United Kingdom. In September 2003, what would later become the AJPP was initiated at a meeting in London hosted by The BMJ (British Medical Journal). $M M J$ was partnered with $J A M A$ as one of the founding partnerships. The other founding partnerships were African Health Sciences (based in Uganda) with The BMJ, the Ghana Medical Journal with The Lancet, and Mali Médical with Environmental Health Perspectives and the American Journal of Public Health. With the United States-based Council of Science Editors (CSE) serving as its administrative body, the AJPP was officially up and running by May 2004, and eleven years, two new partnerships (and two additional African journals joining existing partnerships) later, the programme is flourishing. The two newer partnerships, added in in 2008, have the Ethiopian Journal of Health Sciences paired with Annals of Internal Medicine, and the Medical Journal of Zambia with the New England Journal of Medicine. In 2013, the Sierra Leone Journal of Biomedical Research joined the Ghana Medical Journal-Lancet pairing and Annales Africaines de Médicine, which is published in the Democratic Republic of Congo, joined the Mali Médical-Environmental Health Perspectives partnership.

During my time as $M M J$ intern prior to this month's meeting, I had only vaguely felt the AJPP's presence. The article detailing the $M M J$ editor and desk editor's 2011 trip to the $J A M A$ offices in Chicago $^{3}$ was one of the first $M M J$ articles I read when I started the job, and my curiosity has occasionally led me to AJPP-related news articles online, the websites of AJPP partner journals, and the AJPP site ${ }^{1}$ and Twitter page (@AJPPEditors). Indeed, my position at $M M J$ was only made possible by the AJPP's existence, and obviously the hardware and software in our office did not just magically appear here, but this meeting was the first time I had the opportunity to experience belonging to the AJPP family.

It did not disappoint.

I went into the venue with an open mind, expecting only that the conference would be educational, that I would be surrounded by wise and experienced professionals, and that if I endured the jam-packed schedule without succumbing to the sleep deprivation accrued from having been on call three times in the preceding ten days, I could possibly absorb some of that wisdom and experience. But thanks to the tangible buzz that could be felt from the very first interactions at breakfast on day one, this conference was not endured; it was savoured. The participants were at once approachable, humble, passionate, and engaging. As the actual proceedings of the meeting flew by, I found myself captivated throughout: from bioethics specialist Prof. Mfutso-Bengo's keynote address, in which he helped define what scientific integrity and ethical research reporting means by citing the Chichewa word choonadi, meaning "that which you can see," and therefore "truth" (Chichewa can be so delightful sometimes); to hearing, from each editor, about all of the successes, challenges, and progress of the African partner journals; to meeting with the editors and participants at tea breaks and meals; to participating in interactive discussions about the ethical implications of hypothetical publicationrelated scenarios; to learning details about what acronyms and organizational names like DOI, CrossRef, EQUATOR, and INASP actually mean-I easily forgot about my sleep deprivation. If some of that does not sound so exciting, I cannot emphasize enough that it was the passion and enthusiasm of the conference participants that made it exciting. As one representative put it when the meeting was wrapping up: "It wasn't even boring!" (as such meetings are supposed to be, right?).

It was far from boring. And judging from the group that was present in Bvumbwe, it is easy to see how the AJPP journals on this continent continue to thrive and grow. Hopefully, this is just the beginning of my contribution to that growth.

Andrew Mataya is the Malawi Medical Journal intern and an intern medical doctor at Queen Elizabeth Central Hospital in Blantyre.

\section{References}

1. History [Internet]. African Journal Partnership Project [cited 2015 Jun]. Available from: http://ajpp-online.org/ about/history.php.

2. Schemm Y. African medical journals partner with leading journals to boost impact: Partnerships help boost the reach, quality and discoverability of African research. 2014 Sep 26 [cited 2015 Jun]. In: Elsevier Connect-Research in the developing world [Internet]. New York: Elsevier. Available from: http://www.elsevier.com/connect/african-medicaljournals-partner-with-leading-journals-to-boost-impact.

3. Bandawe C, Kavinya T. Report on site visit to JAMA. Malawi Med J. 2011;23(1):27-28. 